\title{
Selected predictors of maternal-fetal attachment in pregnancies with congenital disorders, other complications, and in healthy pregnancies
}

\section{BACKGROUND}

The mother-infant attachment begins to form during pregnancy and is important for the future development of the child. Pregnancy complications can affect this relationship. The purpose of the study was to identify predictors of maternal-fetal attachment in physiological and high-risk pregnancies.

\section{PARTICIPANTS AND PROCEDURE}

The study group included women in pregnancies with congenital disorders $(n=65)$ or with other pregnancy complications $(n=65)$. A third group included women in healthy pregnancies $(n=65)$. Data were collected by: the MaternalFetal Attachment Scale, the Questionnaire of Attachment Styles, the Rosenberg Self-Esteem Scale, the State-Trait Anxiety Inventory, the Social Support Scale, a standardized interview, the Dependency on Intimate Partner Scale, and the Pregnancy Experiences Scale.

\section{RESULTS}

No significant differences in maternal-fetal attachment (MFA) were found between the groups. No predictors of MFA were observed for the women with a pregnancy with

\begin{abstract}
a congenital disorder. In the group of pregnancies with other complications, the only predictor of attachment intensity was pregnancy experience: a more negative attitude toward pregnancy was associated with lower MFA. In physiological pregnancies, MFA was found to be determined by pregnancy experience, gestational age, maternal age and dependency on one's intimate partner. MFA increased as pregnancy progressed. Younger mothers in physiological pregnancies, who have more positive pregnancy experiences and are less dependent on a partner, achieve higher levels of MFA.
\end{abstract}

\section{CONCLUSIONS}

The presence of high-risk pregnancy, or its absence, does not differentiate the intensity of the emotional bond between mother and fetus. However, women with healthy pregnancies demonstrate different predictors of MFA than those with high-risk pregnancies.

\section{KEY WORDS}

high-risk pregnancy; pregnancy experience; prenatal attachment

Organization - Institute of Psychology, University of Lodz, Lodz, Poland

AUthors' Contributions - A: Study design - B: Data collection - C: Statistical analysis - D: Data interpretation .

E: Manuscript preparation · F: Literature search · G: Funds collection

Corresponding AUthor - Marta Kucharska, Ph.D., Institute of Psychology, University of Lodz, 10/12 Smugowa Str.,

91-433 Lodz, Poland, e-mail: marta.kucharska@uni.lodz.pl

TO CITE THIS ARTICLE - Kucharska, M. (2021). Selected predictors of maternal-fetal attachment in pregnancies

with congenital disorders, other complications, and in healthy pregnancies. Health Psychology Report, 9(3), 193-206.

https://doi.org/10.5114/hpr.2020.97295

RECEIVED 07.04.2020 • REVIEWED 13.06.2020 • ACCEPTED 15.06.2020 • PUBLISHED 15.07.2020 


\section{BACKGROUND}

The attachment between mother and infant begins to form during pregnancy and is important for the later development of the child (Doan \& Zimerman, 2003; Lindgren, 2001; Muller, 1996). The relationship between the pregnant woman and her developing fetus can be modelled using a construct entitled maternal-fetal attachment (MFA), which describes the process by which an expectant mother experiences and expresses feelings for her unborn child (Salisbury et al., 2003). Cranley (1981) describes the MFA concept as "the extent to which women engage in behaviors that represent affiliation and interaction with their unborn child" (Cranley, 1981, p. 282). Pregnancy complications can affect the quality of this relationship, as well as maternal attitudes and behaviors (Yercheski et al., 2009). The information about the birth defect of a child has an emotional impact on parents. The initial parental reaction to the diagnosis is compared to the mourning process in which gradual adaptation leads to better emotional wellbeing (Fonseca \& Canavarro, 2010). Additionally, the diagnosis of fetus malformations or pregnancy complications could be a major stressor during pregnancy, associated with higher levels of anxiety and depression (Asplin et al., 2015; da Cunha et al., 2016). At the same time, most studies have not shown a relationship between depression during pregnancy and prenatal attachment (see: Rollè et al., 2020). Pregnant women with fetal congenital disorders diagnosed in the second trimester initially experienced high levels of stress, but during pregnancy their stress decreased compared to pregnant women without a prenatal diagnosis (Kaasen et al., 2017).

Much attention has been paid to identifying predictors of the relationship between the mother and fetus. Many researchers emphasize the importance of age for prenatal attachment, indicating that younger mothers form a stronger relationship with the unborn child than older ones (Berryman \& Windridge, 1996, following: Bielawska-Batorowicz, 2006; Siddiqui et al., 1999; Ustunsoz et al., 2010). Older women are more likely to experience difficulties during pregnancy; therefore, it is possible that they may express a lower level of involvement with the expected child to protect against potential emotional loss, especially in the first weeks of pregnancy (Bielawska-Batorowicz, 1995). However, Abasi et al. (2013) did not observe such a relationship between the age of the mother and her relationship with the fetus.

Relationship formation has been reported during the 10th week (Laxton-Kane \& Slade, 2002) and the 9th week of pregnancy (Kuo et al., 2013). Many studies indicate that the maternal-fetal attachment becomes more intense over the course of pregnancy (Bielawska-Batorowicz, 1995, 2006; Caccia et al.,
1991; Delavari et al., 2018; Hjelmstedt et al., 2006; Kuo et al., 2013; Laxton-Kane \& Slade, 2002; McNamara et al., 2019; Narita \& Meahra, 1993; Pawlicka et al., 2013; Sjörgen et al., 2004; Walsh et al., 2014). A metaanalysis of 183 studies showed that the best predictor of the prenatal attachment intensity is the duration of pregnancy (Yercheski et al., 2009).

This same meta-analysis found that pregnancy complications have little impact on the development of the relationship with the child (Yercheski et al., 2009). The anticipation or ambiguity of diagnosis, the need for hospitalization and fears for the fetus are accompanied by severe anxiety, i.e. a sense of tension and stress (Rutkowska et al., 2011). What is very interesting, hospitalization in high-risk pregnancy is not significant for prenatal attachment (Palma et al., 2020). Bielawska-Batorowicz and Siddiqui (2008), comparing Polish and Swedish women in healthy and complicated pregnancies, observed that Polish mothers have lower attachment in high-risk pregnancies and Swedish mothers in uncomplicated pregnancies. Pawełczyk et al. (1999) found no differences in the prenatal relationship between healthy and diabetic women, as did Chazotte et al. (1995). Similarly, no differences in the intensity of prenatal attachment were found between women in high-risk and physiological pregnancies (Kemp \& Page, 1987; Pisoni et al., 2015; Ustunsoz et al., 2010; Zimerman \& Doan, 2003). Asplin et al. (2015) state that women express similar attachment to the fetus regardless of the finding of the defect.

Also, the degree of self-esteem demonstrated by the mother has a direct impact on her emotional attachment to the fetus (Abasi et al., 2013). Women with higher self-esteem establish a stronger relationship with their unborn children (Koniak-Griffin, 1988; Muller, 1992). Negative self-image can be an obstacle in the process of entering the parental role. Women who assess their competences as low, or who perceive themselves as insufficiently fit, wise or strong, may consider themselves unable to satisfactorily fulfill their maternal role (Włodarczyk, 2012).

Hee and Young (2015) state that anxiety is the most important predictor of mother-fetus relationships in high-risk pregnancies. It has also been found that higher levels of maternal anxiety are associated with a weaker relationship with the child (Hopkins et al., 2018; Narita \& Meahara, 1993). Mothers at risk of premature delivery experience stronger anxiety (Pisoni et al., 2015), and this mediates the relationship between risk assessment and attachment to a child (White et al., 2008).

A key role in prenatal attachment is played by the previous experiences of the expectant mother in relation to her own mother (Radovanović \& Mihić, 2018; Tani et al., 2018). Research by Siddiqui et al. (2000) indicates that stronger relationships are observed between the mother and unborn child when 
the mother had a more positive relationship with her own mother. Chrzan-Dętkoś and Łockiewicz (2015) showed the importance of romantic attachment style for MFA. In their research anxious-ambivalent style proved to be an important predictor of interaction with the fetus and attributing characteristics to the fetus. Researchers have also observed the coexistence of a secure attachment style with role taking and of avoidant attachment style with more intense attributing characteristics to the fetus. In addition, women with a secure attachment style exhibit a stronger relation with the unborn child as early as the first trimester of pregnancy, while those with predominantly insecure styles establish a less intense prenatal attachment (Mikulincer \& Florian, 1999). Expectant women demonstrating secure attachment have more positive expectations of parenthood than those with insecure attachment (Zaki et al., 2020).

Prenatal attachment is also determined by the marital status of the expectant mother and her relationship with her partner (Yercheski et al., 2009), as well as the positive attitude and reaction of the spouse to the news of becoming pregnant (Kroelinger \& Oths, 2000). In contrast, a negative attitude by the partner corresponds to a less intense attachment with the child (Lumley, 1982; Narita \& Meahara, 1993). A number of studies have also confirmed the importance of satisfaction with the relationship with the partner and social support in strengthening the mother-fetus relationship: Abasi et al. (2012), Abasi et al. (2013), Alhusen (2008), Hjelmstedt et al. (2006), Koniak-Griffin (1988), Kuo et al. (2013), Mercer and Ferketich (1990), Pawlicka et al. (2013), Siddiqui et al. (1999), Walsh et al. (2014) and Yarcheski et al. (2009). However, such support significantly favors more personal treatment of the unborn child and greater interaction with it, but only during subsequent pregnancies. In the first pregnancy, the level of support did not affect the nature of the relationship with the child (Pawlicka et al., 2013); nor did it influence those of prenatal attachment in high-risk pregnancy (Mercer et al., 1988). In contrast, Jang et al. (2015) noted that among women abandoned by the fathers of the child, their self-esteem partly mediates the relationship between social support and prenatal attachment.

Social support for mothers has been found to increase with the risks associated with pregnancy, and this provides a certain buffer against stress (Gebuza et al., 2015). However, although Pisoni et al. (2015) did not report any differences between women in physiological pregnancies and those at risk of premature delivery with regard to the declared intensity of support received, they note that help from loved ones favors the development of a stronger relationship with the child (cf. Fuller et al., 1993; Ossa et al., 2012).
The purpose of this study was to compare the intensity of maternal-fetal attachment in physiological and high-risk pregnancies, either those with a congenital disorder or with other complications. It also examines which of the selected variables (pregnancy experiences, gestational age, mother's age, attachment styles, self-esteem, anxiety, social support and dependency on intimate partner) are predictors of the emotional attachment between the mother and her unborn child in healthy and high-risk pregnancies.

\section{PARTICIPANTS AND PROCEDURE}

\section{PARTICIPANTS}

The study involved 195 Polish women in the second and third trimesters of pregnancy. The participants were divided into three groups according to the nature of the pregnancy. The first was characterized by a congenital disorder such as heart disease, obstructive uropathy, kidney cyst and tumor, gastroschisis or hydrocephalus $(n=65)$. The second group had other pregnancy complications, such as bleeding, abdominal pain and cramping, severe vomiting or incompetent cervix, or various maternal illnesses $(n=65)$. The third group included women experiencing a physiological pregnancy $(n=65)$, also referred to as healthy pregnancies, in which no fetal development disorders or concomitant maternal diseases were present, and during which the subjects were not hospitalized.

The gestational age ranged from 22 to 40 weeks $(M=31)$. No statistically significant differences in the mean week of pregnancy were found between the groups, $F(2,192)=0.10, p=.909$. Primiparous pregnancies were observed in $48 \%$ of the group with birth defects, $59 \%$ with other conditions, and $91 \%$ of women in healthy pregnancies. The current pregnancy was planned by $79 \%$ of women in the group with congenital malformations, $83 \%$ for other risks and $89 \%$ in healthy pregnancies. Previous negative reproductive experience was reported by $46 \%$ of participants with birth defects, $53 \%$ with other complications and $22 \%$ in physiological pregnancies.

\section{MEASURES}

The following data collection instruments were used: The Maternal-Fetal Attachment Scale (MFAS) by Cranley (1981), adapted by Bielawska-Batorowicz (1995), is used to measure various aspects of the mother-fetus relationship during pregnancy. The MFAS consists of 24 statements evaluated on a fivepoint scale. The statements are assigned to five subscales: Role-taking, Differentiation of self from fetus,
Predictors of maternal-fetal attachment in healthy and high-risk pregnancies 
Table 1

Participant characteristics

\begin{tabular}{|c|c|c|c|c|}
\hline \multirow{2}{*}{ Marta Kucharska } & $F=0.28, p>.05$ & $M=29.69$ & $M=30.32$ & $M=30.00$ \\
\hline & Gestational age & $22-40$ & $22-40$ & $22-40$ \\
\hline & $F=0.10, p>.05$ & $M=31.06$ & $M=31.06$ & $M=30.68$ \\
\hline & \multicolumn{4}{|l|}{ Parity } \\
\hline & Primipara & $31(47.7 \%)$ & $38(58.5 \%)$ & $59(90.8 \%)$ \\
\hline & Multipara & $34(52.3 \%)$ & $27(41.5 \%)$ & $6(9.2 \%)$ \\
\hline & \multicolumn{4}{|l|}{ Planned pregnancy } \\
\hline & Yes & $51(78.9 \%)$ & $54(83.1 \%)$ & $58(89.2 \%)$ \\
\hline & No & $14(21.5 \%)$ & $11(16.9 \%)$ & $7(10.8 \%)$ \\
\hline & \multicolumn{4}{|c|}{ Procreation complications } \\
\hline & Yes & $30(46.2 \%)$ & $35(53.8 \%)$ & $14(21.5 \%)$ \\
\hline & No & $35(53.8 \%)$ & $30(46.2 \%)$ & $51(78.5 \%)$ \\
\hline & \multicolumn{4}{|l|}{ Marital status } \\
\hline & Marriage & $53(81.5 \%)$ & $48(73.8 \%)$ & $52(80.0 \%)$ \\
\hline & Cohabitation & $12(18.5 \%)$ & $17(26.2 \%)$ & $13(20.0 \%)$ \\
\hline
\end{tabular}

Interaction with fetus, Attributing characteristics to fetus, Giving of self (Bielawska-Batorowicz, 1995; Cranley, 1981). In the Polish language version, Cronbach's $\alpha$ coefficient is .81 for the total questionnaire and $.66, .58, .52, .61, .50$ for the individual scales; for the examined group, it is .79 for the whole scale and $.64, .57, .52, .59, .48$ for the subscales.

The Questionnaire of Attachment Styles (KSP) by Plopa (2008a) is used to examine attachment styles in partner (romantic) relationships based on the concept of Hazan and Shaver (1987). It consists of 24 items which are evaluated by the respondent on a seven-point scale. The scale measures one Secure attachment style and two Insecure attachment styles: Anxious-ambivalent attachment and Avoidant attachment. Higher scores indicate a higher attachment style. The reliability of some dimensions is satisfactory, and amounts to $.91, .78, .80$, respectively (Plopa, 2008a, 2008b) and in the examined group: $.90, .76, .77$.

The State-Trait Anxiety Inventory (STAI) by Spielberger et al. (1970), adapted by Spielberger et al. (1987), consists of two parts containing 20 questions. The first part is used to study anxiety as a perceived state at a given moment, understood as transient and situational. Part two explores anxiety, understood as a relatively constant personality trait. Cronbach's $\alpha$ coefficient is .90 for the X-1 scale, and .88 for the X-2 scale (Wrześniewski et al., 2006). The same results were obtained for the examined group.

The Self-Esteem Scale (SES) by Rosenberg (1965), adapted by Łaguna et al. (2007) is used to measure global self-esteem, which is considered a relatively permanent feature, not a temporary condition. The tool comprises 10 items, which are evaluated by the respondent on a four-point scale. A higher score indicates higher self-esteem of the respondent. Cronbach's $\alpha$ ranges between .81 and .83 depending on the study group and for the examined sample is .80 .

The Pregnancy Experience Scale by Szymona and Steuden (Szymona-Pałkowska, 2005) is used to assess attitudes towards pregnancy based on five dimensions: Fear of motherhood, Low sense of security in relationship, Excessive focus on pregnancy, Difficulties in trusting oneself and obtaining support, Difficulty in accepting the role of motherhood. The final version of the scale contains 30 items, evaluated on a four-point scale from 0 to 3 (Szymona-Pałkowska, 2005). For the purpose of conducting analyses based on structural modeling, the general indicator "Preg- 
nancy experience", which is the sum of points collected in the five described factors, was created. A higher score indicates a more difficult and more aggravating experience related to pregnancy. Cronbach's $\alpha$ coefficient for subsequent scales is $.84, .73, .54, .61, .56$ and in the examined group: .84, .74, .60, .63, .58.

The Social Support Scale by Kmiecik-Baran (1995), based on the assumptions of Tardy's concept (1985), examines the type and strength of support received from various social groups. Its design was based on support from the partner. It evaluates four categories: emotional support, appraisal support, instrumental support, information support. The scale contains 24 statements and the questionnaire items are rated on a five-point scale, with higher scores indicating lower support (Kmiecik-Baran, 1995). The scale achieves satisfactory statistical properties: .70-.82. In the present research Cronbach's $\alpha$ coefficient for the global scale was .81.

The Dependency on Intimate Partner Scale (SZM) by Babiuch and Kriegelewicz (2000) is used to measure the mutual dependence of partners in a lasting relationship. It diagnoses the properties of a relationship, understood as seeking help from a partner, expecting interest and care, expressing fear of breaking up and belief that the relationship is an essential condition for happiness. The scale contains 28 statements which the respondents evaluate based on a four-point scale. A higher score indicates a greater dependency on the partner (Babiuch \& Kriegelewicz, 2000). Cronbach's $\alpha$ coefficient was .95 - a similar result was obtained for the study group.

A personal and demographic information questionnaire was also constructed to obtain demographic data about previous reproductive experience and medical information about the current pregnancy.

\section{RESULTS}

Analysis showed that the mean intensity of the maternal relationship with the fetus among the examined women is 92.83 , with a standard deviation of 11.88 (mean score 3.87 on a scale of $1-5 ; S D=0.67$ ). In the examined group, the score ranges from 80.95 to 104.71 .

The comparison of MFA intensity by analysis of variance (ANOVA) revealed no significant differences between the three groups, $F(2,192)=.35, p>.05$. In addition, no intergroup differences were observed in the intensity of MFA components (Table 2).

The interrelationships between variables were assessed and the theoretical model was verified based on theoretical assumptions and previous calculations based on structural equation modelling (SEM). The initial model, presented in Figure 1, comprises the following variables and paths: week of pregnancy, experiencing pregnancy (the sum of points obtained for its five aspects: fear of motherhood, disturbed sense of security, lack of confidence in oneself and specialists, concentration on pregnancy and nonacceptance of parental role - a high result means a more negative attitude towards pregnancy), maternal age, secure or insecure attachment style, selfesteem, anxiety as a trait, anxiety as a state, dependence on the partner and support from the partner (a high score means a lower assessment of received support). These variables can be organized into four categories: features of the current pregnancy, individual characteristics of the mother and relationship with the partner.

The initial model (Figure 1) proved to be a poor fit to the data, as indicated by the results of the chisquare analysis, i.e. $\chi^{2}(117)=526.18, p<.001$, which means that there is a discrepancy between the theoretical and observed variance-covariance matrix. For the presented model, CMIN/ $d f$ amounted to 4.50 . It is recommended to reject the model if its value exceeds 2 (Bedyńska \& Książek, 2012). In addition, the root mean square error of approximation divergence ratio exceeds $0.1($ RMSEA $=0.135)$, which also indicates an unacceptable fit.

The model was trimmed further based on empirical data, removing paths that were non-significant and also theoretically sensible, to achieve a parsimonious yet interpretable version. Model fit was improved by the removal of nonsignificant variables (secure attachment, state and trait anxiety) and paths. The final simplified model contained eight variables: pregnancy week, maternal age, experiencing pregnancy, attachment style (secure, insecure), self-esteem, dependence on and support from the partner and maternal-fetal attachment. No discrepancy was found between the theoretical and observed variance-covariance matrix: $\chi^{2}(33)=61.05$, $p=.056$. In addition, the CMIN $/ d f$ measure (1.36) does not exceed the lowest critical value and RMSEA $=0.04$, both of which indicate a good fit of the model; $\alpha=.05$, power $=0.74$. Multiple-group SEM was used to test whether the same model held for women in high-risk pregnancy groups vs healthy pregnancy group (Figures 2-4).

The analysis of the value of path coefficients included in the model shows that in the group of women with congenital disorders (Figure 2), none of the introduced variables is associated with maternal-fetal attachment. However, it was observed that the insecure attachment style exerts a significant influence on the self-esteem of women in this group by affecting the experience of current pregnancy: a high result indicates a negative experience of pregnancy.

A simplified model for the group of pregnant women with other complications is given in Figure 3. Analysis of the value of path coefficients shows that only the pregnancy experiences have a direct impact
Predictors of maternal-fetal attachment in healthy and high-risk pregnancies 
Table 2

Intensity of maternal-fetal attachment (MFA) in high-risk (with congenital disorders or with other complications) and healthy pregnancies: one-way ANOVA

Marta Kucharska

\begin{tabular}{|c|c|c|c|c|c|c|}
\hline & & \multicolumn{2}{|c|}{ High-risk pregnancies } & \multirow{2}{*}{$\begin{array}{c}\text { Healthy } \\
\text { pregnancies } \\
n=65\end{array}$} & \multirow[t]{2}{*}{$F$} & \multirow[t]{2}{*}{$p$} \\
\hline & & $\begin{array}{c}\text { with congenital } \\
\text { disorders } \\
n=65\end{array}$ & $\begin{array}{c}\text { with other } \\
\text { complications } \\
n=65\end{array}$ & & & \\
\hline \multirow{4}{*}{$\begin{array}{l}\text { Interaction } \\
\text { with fetus }\end{array}$} & M & 18.29 & 17.65 & 18.80 & 2.26 & .108 \\
\hline & $\min$ & 8 & 8 & 12 & & \\
\hline & $\max$ & 25 & 25 & 25 & & \\
\hline & $S D$ & 3.08 & 3.52 & 2.65 & & \\
\hline \multirow[t]{4}{*}{ Giving of self } & $M$ & 20.52 & 20.62 & 20.54 & 0.02 & .981 \\
\hline & $\min$ & 10 & 8 & 14 & & \\
\hline & $\max$ & 25 & 25 & 25 & & \\
\hline & $S D$ & 2.52 & 3.45 & 2.69 & & \\
\hline \multirow{4}{*}{$\begin{array}{l}\text { Differentiation } \\
\text { of self from } \\
\text { fetus }\end{array}$} & $M$ & 16.69 & 16.89 & 16.78 & 0.08 & .921 \\
\hline & $\min$ & 10 & 4 & 7 & & \\
\hline & $\max$ & 20 & 20 & 20 & & \\
\hline & $S D$ & 2.49 & 3.34 & 2.51 & & \\
\hline \multirow[t]{4}{*}{ Role-taking } & $M$ & 16.48 & 16.11 & 16.72 & 0.65 & .521 \\
\hline & $\min$ & 9 & 6 & 7 & & \\
\hline & $\max$ & 20 & 20 & 20 & & \\
\hline & $S D$ & 2.78 & 3.42 & 3.02 & & \\
\hline \multirow{4}{*}{$\begin{array}{l}\text { Attributing } \\
\text { characteristics } \\
\text { to fetus }\end{array}$} & $M$ & 21.49 & 20.57 & 20.34 & 1.31 & .273 \\
\hline & $\min$ & 12 & 8 & 8 & & \\
\hline & $\max$ & 30 & 28 & 29 & & \\
\hline & $S D$ & 4.14 & 4.11 & 4.66 & & \\
\hline \multirow[t]{4}{*}{ MFA } & $M$ & 93.48 & 91.83 & 93.18 & 0.35 & .703 \\
\hline & $\min$ & 67 & 44 & 55 & & \\
\hline & $\max$ & 112 & 114 & 111 & & \\
\hline & $S D$ & 10.92 & 13.69 & 10.95 & & \\
\hline
\end{tabular}

on the mother-fetus relationship (-.41); however, this value explains $18 \%$ of the variance of the dependent variable, i.e. MFA $\left(R^{2}=.18\right)$. A perception of the current pregnancy as more aggravating, absorbing, stressful or disturbing reduces the degree of prenatal attachment.

In addition, the following variables had an indirect influence on the strength of MFA: pregnancy week, maternal age, maternal self-esteem, insecure style and support from a partner. These variables modify the way the mother experiences pregnancy $\left(R^{2}=.50\right)$, affecting her relationship with her unborn child. As pregnancy progresses, negative attitudes towards experiencing it increase (.32). The experience of pregnancy is also influenced by maternal age $(-.21)$ : older women tended to have more positive attitudes towards pregnancy. In addition, a high intensity of the insecure attachment style favors a negative attitude towards pregnancy experiences (.36). Interestingly, the insecure style also indirectly affects the experience of the current pregnancy affecting support from a partner (.46), with a high score indicating low social support and self-esteem (-.40). On the other hand, low self-esteem of the mother 


\section{Figure 1}

The initial model of the relationship between selected aspects of the functioning of pregnant women and the maternal-fetal attachment (MFA)

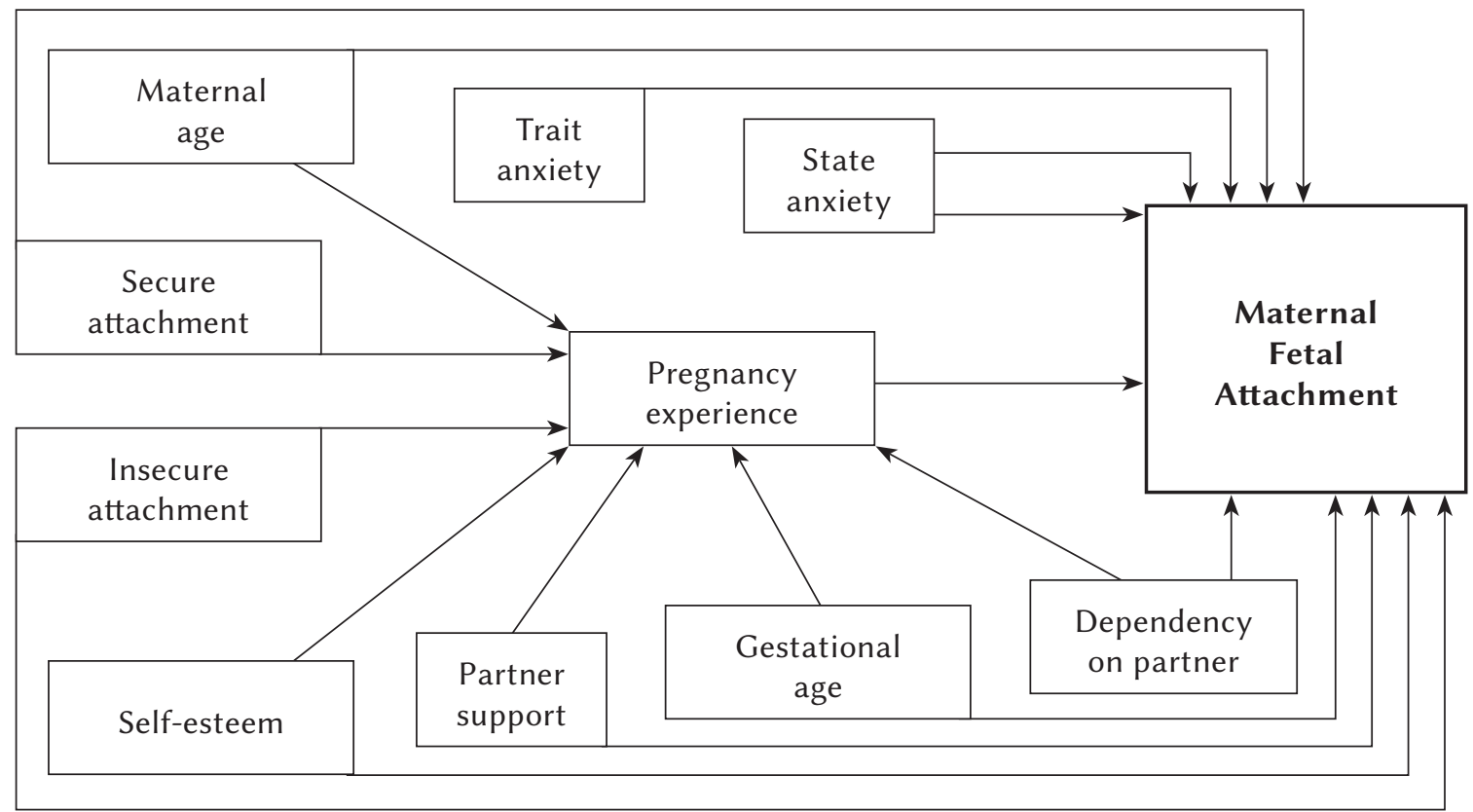

Predictors of maternal-fetal attachment in healthy and high-risk pregnancies

Figure 2

Final trimmed model depicting significant predictors of MFA in pregnancies with congenital disorders (standardized coefficients)

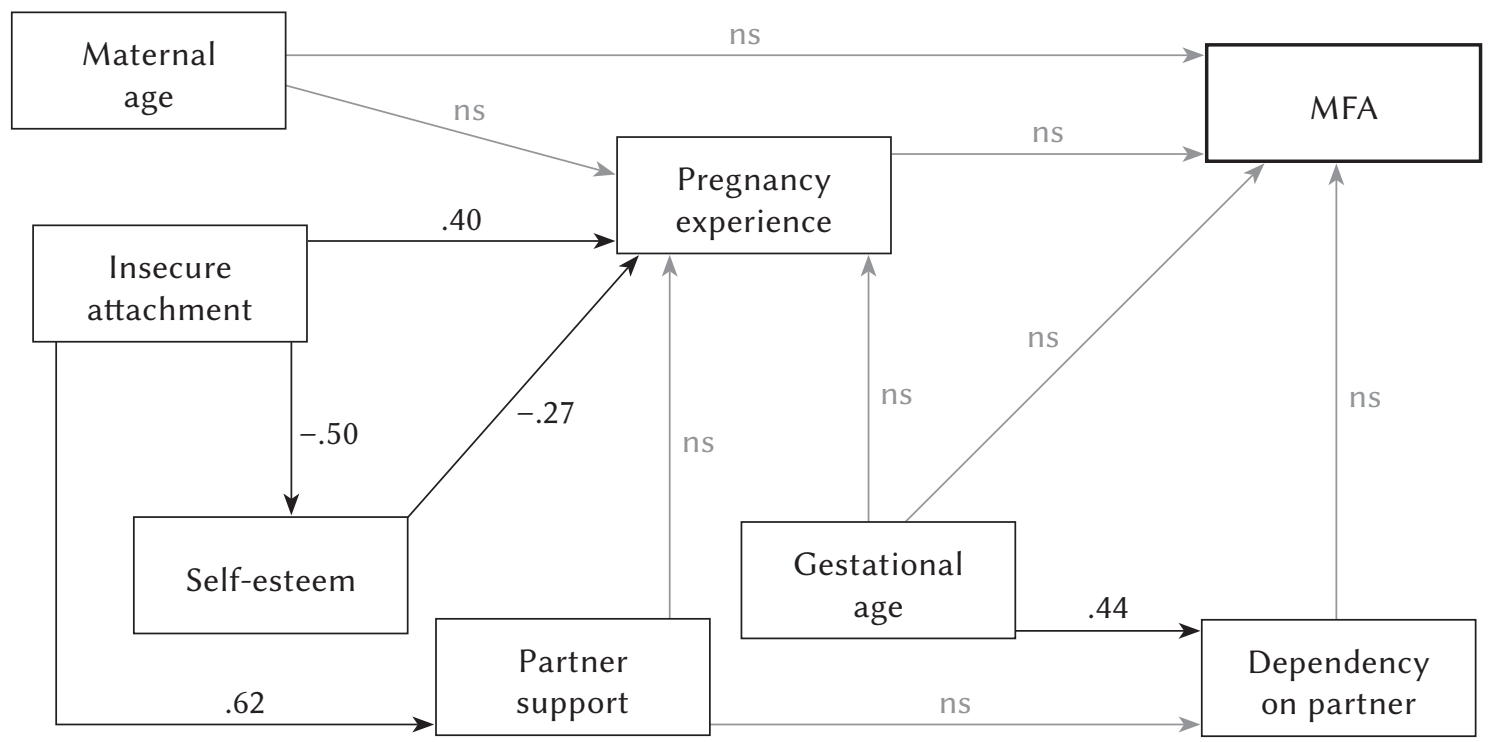

$(-.19)$ and insufficient support from the father of the child (.22) both have a negative impact on her pregnancy experiences. It was also observed that women who receive unsatisfactory support from partners are more dependent on them (.31), which means that they expect interest, care and help from them (Figure 3).
The trimmed model for women in healthy pregnancies (Figure 4) indicates that four variables have a direct impact on MFA, explaining $24 \%$ of the variance of the variable $\left(R^{2}=.24\right)$. The predictor of prenatal attachment is maternal age (-.23): older mothers establish a less intense relationship with the unborn child. Furthermore, as expected, the week of preg- 
Figure 3

Final trimmed model depicting significant predictors of MFA in pregnancies with other complications (standardized coefficients)

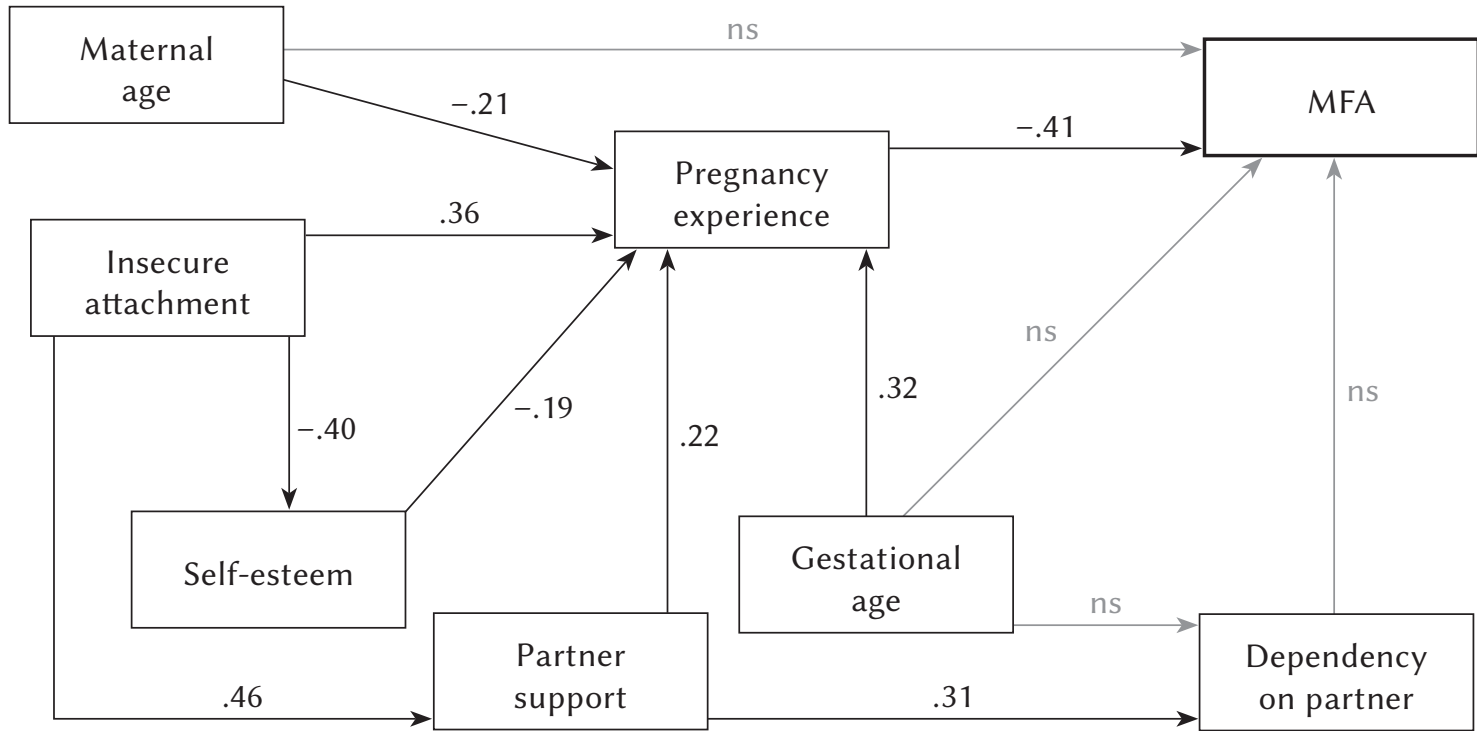

Figure 4

Final trimmed model depicting significant predictors of MFA in healthy pregnancies (standardized coefficients)

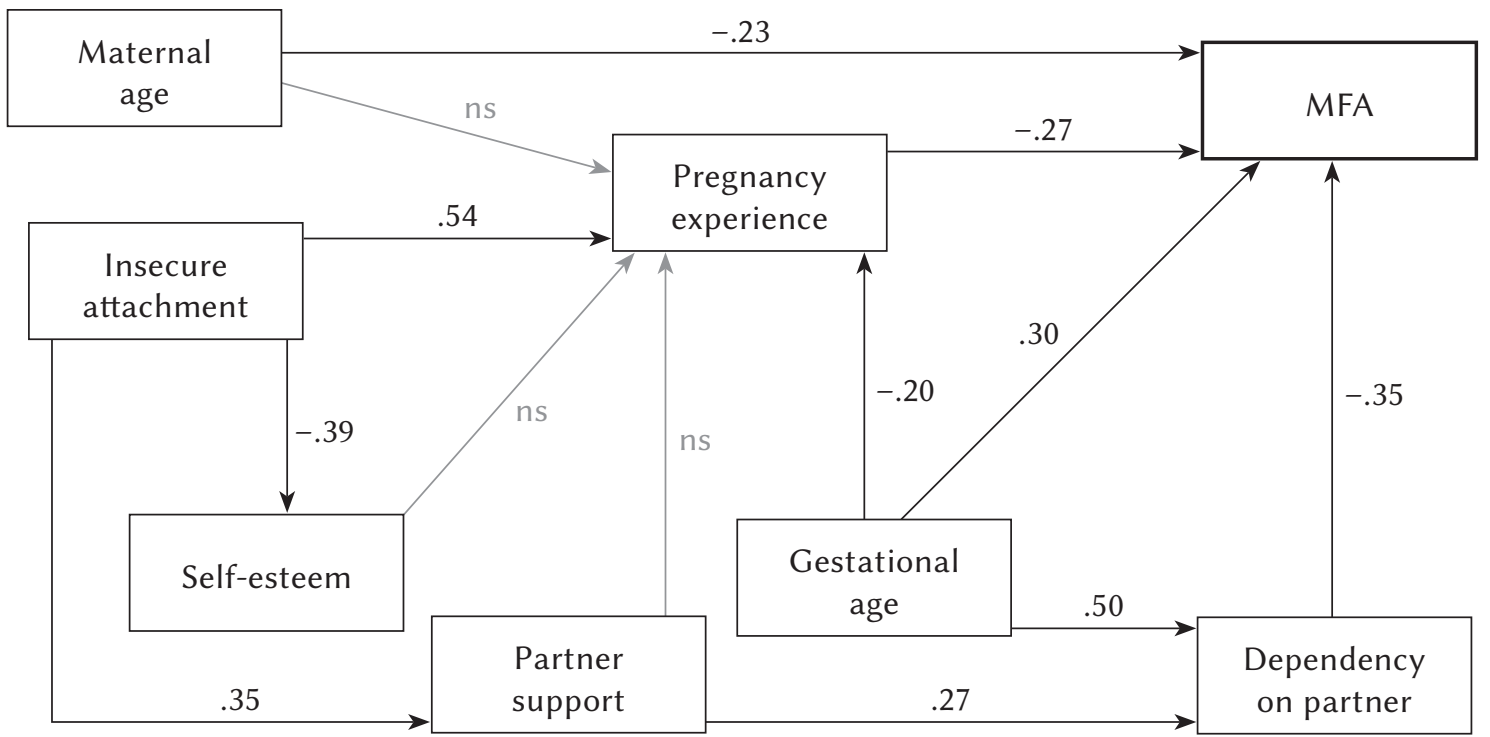

nancy is positively associated with MFA (.30). In turn, the intensification of the mother-fetus relationship is reduced by negative experience of pregnancy $(-.27)$ and higher dependence on the partner (-.35).

The interpretation of path coefficients also indicates that the examined variables have indirect influences on prenatal attachment. The insecure attachment style enhances the negative experience of pregnancy (.54) and is associated with a more negative assessment of support from a partner (.35). In turn, women dissatisfied with support expect more help and care from their partners, so they are more dependent on them (.27). In addition, as pregnancy progresses, it is perceived as less burdensome (-.20), while dependence on the partner increases (.50). It has also been observed that an insecure style reduces the self-esteem of mothers (-.39).

The obtained results confirm the hypothesis that the predictors of maternal-fetal attachment differ between women in healthy pregnancies and those in high-risk pregnancies, i.e. those with congenital disorders or other complications. 


\section{DISCUSSION}

The comparative analyses did not reveal any statistically significant differences in the intensity of the maternal-fetal attachment between the women in physiological pregnancies and those in pregnancies with congenital disorders or other complications. Similar results were obtained in comparisons taking into account planning and the order of pregnancy, as well as previous reproductive experience (data not presented in the article). The obtained results are consistent with those presented by Kemp and Page (1987), Ustunsoz et al. (2010) and Pisoni et al. (2015), who did not find any such differentiation between women in healthy and high-risk pregnancies. Pawełczyk et al. (1999) and Chazotte et al. (1995) also found that the risk of maternal diseases during pregnancy did not affect prenatal attachment. Bieleninik et al. (2010) did not observe differences in MFA intensity between women in unifetal pregnancies and multifetal pregnancies, which are treated as highrisk pregnancies. However, Bielawska-Batorowicz and Siddiqui (2008) found prenatal attachment to be less intense when the pregnancy is at risk among a group of Polish women.

The lack of differentiation in intensity of prenatal attachment between the studied groups does not support the hypothesis that women in pregnancies with birth defects form a less intense relationship with children than those in physiological pregnancies or in pregnancies with other complications. This may be a consequence of the fact that the lowest gestational age was in the 22nd week, i.e. the second half of the second trimester. Researchers agree that the attachment increases as pregnancy develops (see: Bielawska-Batorowicz, 1995, 2006; Laxton-Kane \& Slade, 2002; Yercheski et al., 2009), which suggests that it was already so strongly developed in the study groups that no significant differences could be observed. This significant limitation demonstrates the need for future longitudinal research, which would involve accompanying the mother at various stages of pregnancy development, and allow diagnosis and therapy to monitor potential changes occurring in her prenatal attachment.

It should also be noted that the subjects from the group of healthy pregnancies were recruited in childbirth classes, while participation in antenatal courses was not reported for the groups at risk. Studies show that pregnant women who attend antenatal courses are more likely to have completed higher education than those who do not (Kwiatek et al., 2011). Research indicates that pregnancy education can modify the prenatal relationship between mother and child (Abasi et al., 2013; Bellieni et al., 2007). In addition, most women using childbirth courses are those in their first pregnancy, which may be important for building relationships.
The performed structural equation modeling (SEM) analysis suggests that, according to predictions, the studied groups were characterized by different determinants of MFA. The results should be interpreted with caution. It seems reasonable to conduct tests in larger groups, because the small number of sample size results in less power of this study. It was found that the variables introduced into the model do not allow for prediction of prenatal attachment in the group of women with congenital disorders. It can therefore be assumed that this relationship is affected by other factors that were not included in the study. Undoubtedly, the detection of a developmental defect in a child is a unique and particularly challenging event. My finding of an association of prenatal attachment predictors with an abnormally developing fetus may be weakened by the fact that the study included a wide range of birth defects, which have varying consequences for the functioning of the child and mother. Some of them can be corrected as soon as in the prenatal period (e.g. obstructive uropathy or some heart defects), while others can be treated only after the birth of the child; in addition, some birth defects have a higher mortality rate, while others affect the structure of the fetus and are noticeable in the appearance of the child after birth (e.g. hydrocephalus).

In contrast, the maternal-fetal attachment experienced by the women in pregnancy with other complications is determined by the negative experience of pregnancy. When the current state is perceived as burdensome and aggravating, mothers build a less intense relationship with their unborn children. According to Szymona-Pałkowska (2005), the experience of pregnancy sets specific tasks and challenges for parents, which may be associated with threats and overloads, in both the emotional and the cognitive sphere. This situation can be considered in terms of psychological stress. High-risk pregnancy, in which the threat is associated with unpleasant ailments for the mother, is an additional physical burden. In the face of so many difficulties experienced, a woman may pay less attention to creating an emotional relation with her child.

In turn, experiencing pregnancy with other complications becomes more negative as pregnancy progresses and is associated with a younger maternal age. Additionally, in this group, pregnancy is perceived as more aggravating by women with an insecure attachment style, low self-esteem and who assess support from their partners as poorer. Previous studies also indicate that women with insecure romantic attachment are less ready for a parental role (Zaki et al., 2020; Zdolska-Wawrzkiewicz et al., 2018). It can be assumed that for the younger women, the current state is a new experience, and hence is associated with stronger fears regarding the parental role, effectiveness of medical care and the reaction
Predictors of maternal-fetal attachment in healthy and high-risk pregnancies 
of the partner (Pawlicka et al., 2013). These feelings intensify with the development of pregnancy, as the mother becomes less independent; this is particularly important in the context of pathological pregnancies, which have a stronger influence on the health of the mother (Heaman, 1998). Therefore, it appears that the self-esteem of the mother may be related to her expectations regarding pregnancy: mothers who are undergoing a difficult pregnancy may feel less effective and may assess their ability to carry out their tasks more poorly. Such low self-esteem is further weakened by a tendency for insecure romantic attachment, which intensifies anxiety regarding rejection and withdrawal: such anxiety may be associated with a less favorable perception of the support received from a partner (Plopa, 2008b).

Among the group of women in physiological pregnancies, prenatal attachment appears to be determined by dependence on the partner, gestational age, pregnancy experiences and maternal age. Surprisingly, the strongest predictor of MFA in healthy pregnancies was found to be dependence on a partner; furthermore, higher dependency in a partnership appears to weaken the prenatal attachment. Previous studies, in contrast, have found that mothers who are more dependent on their partners tend to expect more care, presence and support from them (Babiuch \& Kriegelewicz, 2000). It may be possible that women who do not have to deal with the difficulties arising from the course of the pregnancy, or have any concerns about the health and life of the child, treat the permanence of relationships with a partner as a condition of happiness; they tend to focus more on their own needs that they can fulfil in a relationship compared to women in high-risk pregnancies.

In addition, it was found that as their pregnancy progresses, the examined mothers become more dependent on their partners and tend to rate their support as lower. The perception that the help provided by a partner is less satisfactory appears to be determined by an insecure attachment style, which is consistent with previous findings (see: Bookwala, 2003; Collins et al., 2002). It can be assumed that the approach of childbirth, and thus the necessity to take up a parental role and responsibilities, triggers a higher need for interest and commitment from the partner. This is further strengthened if such help is regarded as insufficient.

The degree of maternal-fetal attachment in a healthy pregnancy also appears to increase as the pregnancy progresses, as indicated in most previous studies (see: Bielawska-Batorowicz, 1995; Caccia et al., 1991; McNamara et al., 2019; Walsh et al., 2014). It is worth highlighting that my present findings indicate that gestational age was a significant predictor of MFA only in the group of healthy women. Perhaps when the pregnancy is not high risk, and when the mother does not have to worry about additional tests and waiting for the diagnosis and prognosis of pregnancy, attachment may grow more gradually as the fetus develops. This allows the mother to respond adequately to fetal development and increase fetal activity in the intrauterine environment by making contact and changing her behavior. Such a process is conducive to the differentiation of self from the fetus and attributing characteristics to it.

Perceiving a healthy pregnancy as more aggravating lowers the MFA. Any changes or symptoms that cause concern can be difficult for the mother to accept, and can disturb her sense of security; they can discourage her from taking on new responsibilities associated with maternity, and prevent her from easily establishing contact with the child and assigning it features. The insecure style, characterized by a tendency to make more pessimistic assessments of the situation (Collins et al., 2002) and difficulties in getting support from a partner (Plopa, 2008a), favors a more negative perception of pregnancy experiences and reduces the self-esteem of the mother. Such a style is also observed among women in healthy pregnancies; however, women in this group, in contrast to those in pregnancies characterized by other complications, are more likely to become accustomed to the challenges it brings, adapt to them, and experience their condition more positively as pregnancy progresses.

The fourth predictor of MFA in uncomplicated pregnancies is maternal age, with younger mothers appearing to establish a stronger relationship with their unborn children than older ones, as confirmed in previous studies (see: Siddiqui et al., 1999; Ustunsoz et al., 2010); however, it should be emphasized that this relationship occurred only in healthy pregnancies. Maternal age is an important risk factor for fetal development and successful delivery - in older women, the risk of pregnancy complications and stillbirth increases significantly. In groups of women with pathological pregnancies, this relationship with age may lack significance because the threat already exists, regardless of age. In contrast, older women experiencing healthy pregnancies can establish a less strong relationship with the unborn child to protect themselves against emotional costs in the event of their loss (Bielawska-Batorowicz, 2005).

Due to the fact that the parent-child relationship begins to form in the prenatal period and has an impact on the quality of mutual relations and functioning in later life, it is important to strengthen and support this bond as early as possible. My present findings highlight the need to improve the care system for pregnant women, which, in addition to specialized medical assistance, would also include psychological assistance in a broader sense. Although the present research did not show intergroup differences, it is extremely important to train health care professionals particularly as regards the 
communication of the diagnosis (Fonseca \& Canavarro, 2010). The possibility of early detection and correction of pregnancy risks allow ample opportunity for educational, preventive and assistance activities addressed to future parents and their families, as well as the specialists taking care of pregnant women. Perwitasari et al. (2019) highlight that the possibility of maternal-fetal attachment education can contribute to improving the mother's mental and physical health. An understanding of the experiences and ways that this special time is experienced by pregnant women and their social environment, especially in cases of high-risk pregnancy, allows an opportunity to offer professional psychological help and adequate support to improve their functioning, increase the sense of satisfaction and strengthen social bonds.

\section{CONCLUSIONS}

The fact that a pregnancy may be high risk or not does not differentiate the intensity of MFA, and women in healthy and high-risk pregnancies present different predictors of MFA. None of the tested variables were found to be predictors for MFA for the mothers experiencing pregnancy characterized by congenital disorders; this suggests that this relationship is influenced by other factors which have not been included in the study. Women in pregnancies with other types of complications who also report strong negative pregnancy experiences exhibit a less intensive relationship with the unborn child. Women in healthy pregnancies demonstrate a less intense attachment with the fetus when they are older, are more dependent on their partner and experience more negative aspects of pregnancy; they were also found to demonstrate a stronger MFA as pregnancy progressed. These differences in the predictors of MFA between the study groups underline the need for further investigations in this area.

\section{References}

Abasi, E., Tafazzoli, M., Esmaily, H., \& Hasanabadi, H. (2013). The effect of maternal-fetal attachment education on maternal mental health. Turkish Journal of Medical Sciences, 43, 815-820. https://doi. org/10.3906/sag-1204-97

Abasi, E., Tahmasebi, H., Zafari, M., \& Nasiri Takami, G. (2012). Assessment on effective factors of maternalfetal attachment in pregnant women. Life Science Journal, 9, 68-75.

Alhusen, J. L. (2008). A literature update on maternalfetal attachment. Journal of Obstetric, Gynecologic and Neonatal Nursing, 37, 315-328. https://doi. org/10.1111/j.1552-6909.2008.00241.x
Asplin, N., Wessel, H., Marions, L., \& Georgsson Öhman, S. (2015). Maternal emotional wellbeing over time and attachment to the fetus when a malformation is detected. Sexual \& Reproductive Healthcare, 6, 191-195. https://doi.org/10.1016/j.srhc.2015.04.003

Babiuch, M. E., \& Kriegelewicz, O. (2000). Skala do pomiaru zależności od wspótmatżonka [The Dependency on Intimate Partner Scale]. Own materials provided by the author of the method.

Bedyńska, S., \& Książek, M. (2012). Statystyczny drogowskaz. Praktyczny przewodnik wykorzystania modeli regresji oraz równań strukturalnych. Tom 3 [Statistical signpost. A practical guide of regression models and structural equations]. Wydawnictwo Akademickie Sedno.

Bellieni, C. V., Ceccarelli, D., Rossi, F., Buonocore, G., Maffei, M., Perrone, S., \& Petriaglia, F. (2007). Is prenatal bonding enhanced by prenatal education courses? Minerva Ginecologica, 59, 125-129.

Berryman, J. C., \& Windridge, K. C. (1996). Pregnancy after 35 and attachment to the fetus. Journal of Reproductive and Infant Psychology, 14, 133-143. https://doi.org/10.1080/02646839608404510

Bielawska-Batorowicz, E. (1995). Determinanty spostrzegania dziecka przez rodziców w okresie poporodowym [Determinants of the perception of the child by parents in the postpartum period]. Wydawnictwo Uniwersytetu Łódzkiego.

Bielawska-Batorowicz, E. (2006). Psychologiczne aspekty prokreacji [Psychological aspects of procreation]. Wydawnictwo Naukowe Śląsk.

Bielawska-Batorowicz, E., \& Siddiqui, A. (2008). A study of prenatal attachment with Swedish and Polish expectant mothers. Journal of Reproductive and Infant Psychology, 26, 373-384. https://doi. org/10.1080/02646830802426144

Bieleninik, Ł., Preis, J., \& Bidzan, M. (2010). Uwarunkowania więzi emocjonalnej z dzieckiem w okresie prenatalnym w ciążach wielopłodowych i pojedynczych [Conditions of the emotional bond with a child in the prenatal period in case of multifetal and unifetal pregnancies]. Perinatologia, Neonatologia i Ginekologia, 3, 223-231.

Bookwala, J. (2003). Being "single and unattached": The role of adult attachment styles. Journal of Applied Social Psychology, 33, 1564-1570. https://doi. org/10.1111/j.1559-1816.2003.tb01963.x

Caccia, N., Johnsson, J. M., Robinsoon, G. E., \& Barna, T. (1991). Impact of prenatal testing on maternal-fetal bonding: chorionic villus sampling versus amniocentesis. American Journal of $\mathrm{Ob}$ stetrics \& Gynecology, 165, 1122-1125. https://doi. org/10.1016/0002-9378(91)90484-9

Chazotte, C., Comerford Freda, M., Elovitz, M., \& Youchah, J. (1995). Maternal depressive symptoms and maternal-fetal attachment in gestational diabetes. Journal of Women's Health, 4, 375-380. https://doi.org/10.1089/jwh.1995.4.375
Predictors of maternal-fetal attachment in healthy and high-risk pregnancies 
Chrzan-Dętkoś, M., \& Łockiewicz, M. (2015). Maternal romantic attachment, and antenatal and postnatal mother-infant attachment in a sample of Polish women. European Journal of Developmental Psychology, 12, 429-442. https://doi.org/10.1080/17 405629.2015.1036024

Collins, N. L., Cooper, M. L., Albino, A. W., \& Allard, L. (2002). Psychosocial vulnerability from adolescence to adulthood: a prospective study of attachment style differences in relationship functioning and partner choice. Journal of Personality, 70, 9651008. https://doi.org/10.1111/1467-6494.05029

Cranley, M. S. (1981). Development of a tool for the measurement of maternal attachment during pregnancy. Nursing Research, 30, 281-284. https:// doi.org/10.1097/00006199-198109000-00008

da Cunha, A. C. B., Pereira Junior, J. P., Caldeira, C. L. V., \& Carneiro, V. M. S. D. P. (2016). Diagnóstico de malformações congênitas: Impactos sobre a saúde mental de gestantes [Diagnosis of congenital malformations: Impact on the mental health of pregnant women]. Estudos de Psicologia, 33, 601-611. https://doi.org/10.1590/198202752016000400004

Delavari, M., Mohammad-Alizadeh-Charandabi, S., \& Mirghafurvand, M. (2018). The relationship between maternal-fetal attachment and maternal self-efficacy in Iranian women: a prospective study. Journal of Reproductive and Infant Psychology, 36, 302-311. https://doi.org/10.1080/02646838. 2018.1436753

Doan, H. M., \& Zimerman, A. (2003). Conceptualizing prenatal attachment: Toward a multidimensional view. Journal of Prenatal and Perinatal Psychology and Health, 18, 109-129.

Fonseca, A., \& Canavarro, M. C. (2010). Parental reactions to perinatal congenital anomaly diagnosis of the baby: Implications for the intervention of health professionals. Psicologia, Saúde \& Doenças, 11, 283-297.

Fuller, S. G., Moore, L. R., \& Lester, J. W. (1993). Influence of family functioning on maternal-fetal attachment. Journal of Perinatology, 13, 453-460.

Gebuza, G., Kaźmierczak, M., Gierszewska, M., Mieczkowska, E., Banaszkiewicz, M., \& Wróbel-Bania, A. (2015). Lek przed porodem w III trymestrze ciąży i jego powiązania ze stanem noworodka [Fear of childbirth in the third trimester of pregnancy and its correlation with the condition of neonate]. Medycyna Ogólna i Nauki o Zdrowiu, 21, 39-44.

Hazan, C., \& Shaver, P. (1987). Romantic love conceptualized as an attachment process. Journal of Personality and Social Psychology, 52, 511-524. https://doi.org/10.1037/0022-3514.52.3.511

Heaman, M. (1998). Psychosocial impact of high-risk pregnancy: Hospital and home care. Clinical $O b$ stetrics and Gynecology, 41, 626-639. https://doi. org/10.1097/00003081-199809000-00017
Hee, L. S., \& Young, L. E. (2015). Factors influencing maternal-fetal attachment in high-risk pregnancy. Advanced Science and Technology Letters, 104, 38-42. Hjelmstedt, A., Widstrom, A. M., \& Collins, A. P. (2006). Psychological correlates of prenatal attachment in women who conceived after in vitro fertilization and women who conceived naturally. Birth, 33, 303-310. https://doi.org/10.1111/j.1523536X.2006.00123.x

Hopkins, J., Miller, J. L., Butler, K., Gibson, L., Hedrick, L., \& Boyle, D. A. (2018). The relation between social support, anxiety and distress symptoms and maternal-fetal attachment. Journal of Reproductive and Infant Psychology, 36, 381-392. https:// doi.org/10.1080/02646838.2018.1466385

Jang, S. H., Kim, I. J., \& Lee, S. H. (2015). Social support and maternal-fetal attachment in unmarried pregnant women in Korea: Does self-esteem play a mediating role? International Journal of Bio-Science and Bio-Technology, 7, 131-140. https://doi.org/ 10.14257/ijbsbt.2015.7.6.14

Kaasen, A., Helbig, A., Malt, U. F., Næs, T., Skari, H., \& Haugen, G. (2017). Maternal psychological responses during pregnancy after ultrasonographic detection of structural fetal anomalies: a prospective longitudinal observational study. PLoS One, 12, e0174412. https://doi.org/10.1371/journal. pone. 0174412

Kemp, V. H., \& Page, C. K. (1987). Maternal prenatal attachment in normal and high-risk pregnancies. Journal of Obstetric, Gynecologic and Neonatal Nursing, 16, 179-184. https://doi.org/10.1111/j. 1552-6909.1987.tb01455.x

Kmiecik-Baran, K. (1995). Skala wsparcia społecznego. Teoria i właściwości psychometryczne [The Social Support Scale. Theory and psychometric properties]. Przeglad Psychologiczny, 38, 201-214.

Koniak-Griffin, D. (1988). The relationship between social support, self-esteem, and maternal-fetal attachment in adolescents. Research in Nursing and Health, 11, 269-278. https://doi.org/10.1002/nur. 4770110408

Kroelinger, C. D., \& Oths, K. S. (2000). Partner support and pregnancy wantedness. Birth, 27, 112-119. https://doi.org/10.1046/j.1523-536x.2000.00112.x

Kwiatek, M., Gęca,T., Biegaj-Fic, J., \& Kwaśniewska, A. (2011). Szkoła rodzenia - profil pacjentek oraz wpływ zajęć na przebieg porodu i stan noworodka [Childbirth classes - patients' profiles and effect of parental education on labour course and infant health outcome]. Medycyna Ogólna i Nauki o Zdrowiu, 17, 111-115.

Kuo, P. C., Bowers, B., Chen, Y. C., Chen, C. H., Tzeng, Y. L., \& Lee, M. S. (2013). Maternal-fetal attachment during early pregnancy in Taiwanese women pregnant by in vitro fertilization. Journal of Advanced Nursing, 69, 2502-2513. https://doi. org/10.1111/jan. 12135 
Laxton-Kane, M., \& Slade, P. (2002). The role of maternal prenatal attachment in a woman's experience of pregnancy and implications for the process of care. Journal of Reproductive and Infant Psychology, 20, 253-266. https://doi.org/10.1080/026468302100 0033174

Lindgren, K. (2001). Relationships among maternal-fetal attachment, prenatal depression, and health practices in pregnancy. Research in Nursing \& Health, 24, 203-217. https://doi.org/10.1002/nur.1023

Lumley,J.M. (1982). Attitudes to the fetus among primigravidae. Journal of Paediatrics and Child Health, 18, 106-109. https://doi.org/10.1111/j.1440-1754.1982. tb02000.x

Łaguna, M., Lachowicz-Tabaczek, K., \& Dzwonkowska, I. (2007). Skala samooceny SES Morrisa Rosenberga - polska adaptacja metody [The Rosenberg Self-Esteem Scale - Polish adaptation of the scale]. Psychologia Spoteczna, 2, 164-176.

McNamara, J., Townsend, M. L., \& Herbert, J. S. (2019). A systemic review of maternal wellbeing and its relationship with maternal fetal attachment and early postpartum bonding. PLoS One, 14, e0220032. https://doi.org/10.1371/journal.pone.0220032

Mercer, R. T., \& Ferketich, S. L. (1990). Predictors of parental attachment during early parenthood. Journal of Advanced Nursing, 15, 268-280. https:// doi.org/10.1111/j.1365-2648.1990.tb01813.x

Mercer, R. T., Ferketich, S., May, K., DeJoseph, J., \& Sollid, D. (1988). Further exploration of maternal and paternal attachment. Research in Nursing and Health, 11, 83-95. https://doi.org/10.1002/ nur.4770110204

Mikulincer, M., \& Florian, V. (1999). Maternal-fetal bonding, coping strategies, and mental health during pregnancy: The contribution of attachment style. Journal of Social and Clinical Psychology, 18, 255-276. https://doi.org/10.1521/jscp.1999.18.3.255

Muller, M. E. (1992). A critical review of prenatal attachment research. Scholarly Inquiry for Nursing Practice, 6, 5-22.

Muller, M. E. (1996). Prenatal and postnatal attachment: a modest correlation. Journal of Obstetric, Gynecologic and Neonatal Nursing, 25, 161-166. https://doi.org/10.1111/j.1552-6909.1996.tb02420.x

Narita, S., \& Maehara, S. (1993). The development of maternal-fetal attachment during pregnancy. Journal of Japan Academy of Nursing Science, 13, 1-9. https://doi.org/10.5630/jans 1981.13.2_1

Ossa, X., Bustos, L., \& Fernandez, L. (2012). Prenatal attachment and associated factors during the third trimester of pregnancy in Temuco, Chile. Midwifery, 28, 689-696. https://doi.org/10.1016/j. midw.2011.08.015

Palma, E., Armijo, I., Cifuentes, J., Ambiado, S., Rochet, P., Díaz, B., Gutierrez, J., \& Mena, C. (2020). Hospitalisation in high-risk pregnancy patients: Is prenatal attachment affected? Journal of Repro- ductive and Infant Psychology, 1-13. https://doi.org/ 10.1080/02646838.2020.1740661

Pawełczyk, A., Cypryk, K., \& Bielawska-Batorowicz, E. (1999). Poziom lęku i więź emocjonalna z dzieckiem w okresie ciąży u kobiet z GDM i zdrowych ciężarnych [Anxiety and maternal-fetal attachment in gestational diabetic women]. Diabetologia Polska, 6, 189-192.

Pawlicka, P., Chrzan-Dętkoś, M., \& Lutkiewicz, K. (2013). Prężność psychiczna przyszłych matek oraz kolejność ciąży jako moderatory budowania więzi z nienarodzonym jeszcze dzieckiem [Resilience of expectant mothers and order of pregnancy as moderators of mother-fetal attachment]. Family Forum, 3, 139-152.

Perwitasari, P., Hakimi, M., \& Anjarwati, A. (2019). The effect of maternal-fetal attachment education on pregnant women's mental health. Journal of Health Technology Assessment in Midwifery, 2, 50-58. https://doi.org/10.31101/jhtam.1043

Pisoni, C., Garofoli, F., Tzialla, C., Orcesi, S., SpiniIlo, A., Politi, P., Balottin, U., Tinelli, C., \& Stronati, M. (2015). Complexity of parental prenatal attachment during pregnancy at risk for preterm delivery. Journal of Maternal-Fetal and Neonatal Medicine, 29, 771-776. https://doi.org/10.3109/147 67058.2015 .1017813

Plopa, M. (2008a). Kwestionariusz Stylów Przywiązaniowych [The Questionnaire of Attachment Styles]. Vizja Press \& IT.

Plopa, M. (2008b). Więzi w matżeństwie i rodzinie. Metody badań [Bonds in marriage and family. Research methods]. Oficyna Wydawnicza Impuls.

Radovanović, M., \& Mihić, I. (2018). Razvoj prenatalne vezanosti u kontekstu iskustva iż porodice porekla [Prenatal attachment in a context of experience of the family of origin]. Primenjena Psihologija, 11, 53-67. https://doi.org/10.19090/pp.2018.1.53-67

Rollè, L., Giordano, M., Santoniccolo, F., \& Trombetta, T. (2020). Prenatal attachment and perinatal depression: a systematic review. International Journal of Environmental Research and Public Health, 17, 2644. https://doi.org/10.3390/ijerph17082644

Rosenberg, M. (1965). Society and the adolescent selfimage. Princeton University Press.

Rutkowska, A., Kowalska, A., Makara-Studzińska, M., \& Kwaśniewska, A. (2011). Analiza struktury osobowości u kobiet w pierwszej ciąży prawidłowej i wysokiego ryzyka [The analysis of the personality structure in primiparas with normal and highrisk pregnancy]. Current Problems of Psychiatry, 12, 420-427.

Salisbury, A., Law, K., Ladasse, L., \& Lester, B. (2003). Maternal-fetal attachment. Journal of the American Medical Association, 289, 1707. https://doi. org/10.1001/jama.289.13.1701

Siddiqui, A., Eisemann, M., \& Hägglöf, B. (1999). An exploration of prenatal attachment in Swed-
Predictors of maternal-fetal attachment in healthy and high-risk pregnancies 
ish expectant women. Journal of Reproductive and Infant Psychology, 17, 369-380. https://doi. org/10.1080/02646839908404602

Siddiqui, A., Hägglöf, B., \& Eisemann, M. (2000). Own memories of upbringing as a determinant of prenatal attachment in expectant women. Journal of Reproductive and Infant Psychology, 18, 67-74. https://doi.org/10.1080/02646830050001690

Sjögren, B., Edman, G., Widsröm, A. M., Mathiessen, A.S., \& Uvnäs-Moberg, K. (2004). Maternal-fetal attachment and personality during first pregnancy. Journal of Reproductive and Infant Psychology, 22, 57-69. https://doi.org/10.1080/0264683042000 205936

Spielberger, C. D., Gorsuch, R. L., \& Lushene, R. E. (1970). Manual for the State-Trait Anxiety Inventory. Consulting Psychologists Press.

Spielberger, C. D., Strelau, J., Tysarczyk, M., \& Wrześniewski, K. (1987). Inwentarz stanu i cechy lęku (polska adaptacja STAI) [The State-Trait Anxiety Inventory (Polish adaptation of STAI)]. Pracownia Testów Psychologicznych PTP.

Szymona-Pałkowska, K. (2005). Psychologiczna analiza doświadczeń rodziców w sytuacji ciąży wysokiego ryzyka [Psychological analysis of parents' experiences in high-risk pregnancy]. Towarzystwo Naukowe Katolickiego Uniwersytetu Lubelskiego.

Tani, F., Castagna, V., \& Ponti, L. (2018). Women who had positive relationships with their own mothers reported good attachments to their first child before and after birth. Acta Paediatrica, 107, 633-637. https://doi.org/10.1111/apa.14162

Tardy, C. H. (1985). Social support measurement. American Journal of Community Psychology, 13, 187-202. https://doi.org/10.1007/BF00905728

Ustunsoz, A., Guvenc, G., Akyuz, A., \& Oflaz, F. (2010). Comparison of maternal- and paternalfetal attachment in Turkish couples. Midwifery, 26, 1-9. https://doi.org/10.1016/j.midw.2009.12.006

Walsh, J., Hepper, E. G., \& Marshall, B. J. (2014). Investigating attachment, caregiving, and mental health: a model of maternal-fetal relationships. BMC Pregnancy and Childbirth, 14, 383-391. https://doi.org/10.1186/s12884-014-0383-1

White, O., McCorry, N. K., Scott-Heyes, G., \& Dempster, M. (2008). Maternal appraisals of risk, coping and prenatal attachment among women hospitalised with pregnancy complications. Journal of Reproductive and Infant Psychology, 26, 74-85. https://doi.org/10.1080/02646830801918455

Włodarczyk, E. (2012). O „rodzeniu się” macierzyństwa [About the "birth" of motherhood. In J. Deręgowska \& M. Majorczyk (Eds.), Konteksty wspótczesnego macierzyństwa. Perspektywa mtodych naukowców [Contexts of modern motherhood. Perspective of young scientists] (pp. 101-127). Wydawnictwo Naukowe Wyższej Szkoły Nauk Humanistycznych i Dziennikarstwa.
Wrześniewski, K., Sosnowski, T., Jaworowska, A., \& Fecenec, D. (2006). Inwentarz Stanu i Cechy Lęku STAI [The State-Trait Anxiety Inventory]. Pracownia Testów Psychologicznych.

Yercheski, A., Mahon, N. E., Yercheski, T.J., Hank, M. M., \& Cannella, B. L. (2009). A meta-analytic study of predictors of maternal-fetal attachment. International Journal of Nursing Studies, 46, 708-715. https://doi.org/10.1016/j.ijnurstu.2008.10.013

Zaki, N., Ruiz-Ruano García, A. M., \& López Puga, J. (2020). Attachment style and prenatal expectations from a Bayesian perspective. Psicothema, 32, 138144. https://doi.org/10.7334/psicothema2019.222

Zdolska-Wawrzkiewicz, A., Chrzan-Dętkoś, M., \& Bidzan, M. (2018). Maternal attachment style during pregnancy and becoming a mother in Poland. Journal of Reproductive and Infant Psychology, 36, 4-14. https://doi.org/10.1080/02646838.2017.1395400

Zimerman, A., \& Doan, H. M. (2003). Prenatal attachment and other feelings and thoughts during pregnancy in three groups of pregnant women. Journal of Prenatal and Perinatal Psychology and Health, 18, 131-148. 